\title{
Recent Developments in Business Lending by Commercial Banks
}

\section{William F. Bassett and Egon Zakrajëek, of the Board's Division of Monetary Affairs, prepared this article. Jason Grimm and Steve Piraino provided research assistance.}

After growing rapidly during much of the $1990 \mathrm{~s}$, the inflation-adjusted value of commercial and industrial (C\&I) loans at domestic commercial banks and at U.S. branches and agencies of foreign banks has fallen 19 percent since the beginning of 2001 (chart 1). ${ }^{1}$ This striking decline in aggregate C\&I loans masks important differences in lending patterns at domestically chartered institutions of different sizes and at U.S. branches and agencies of foreign banks. A drop in loans at large domestic commercial banks and at foreign institutions accounts for the entire contraction in C\&I loans since January $2001 .^{2}$ In contrast, the real growth rate of business loans at small commercial banks, though it has declined appreciably, has averaged almost 4 percent annually since early 2001. The recent runoff in C\&I loans contrasts sharply with that of the early $1990 \mathrm{~s}$ : The earlier contraction in lending at large and small domestic banks was more uniform and was partly offset by a robust expansion of business loans at foreign institutions (chart 2).

Although branches and agencies of foreign banks are important participants in the C\&I loan market,

1. C\&I loans are business loans not secured by real estate.

2. Banks consist of the following types of institutions in the fifty states and the District of Columbia: domestically chartered commercial banks that submit a weekly report of condition (large domestic); other domestically chartered commercial banks (small domestic); branches and agencies of foreign banks, and Edge Act and agreement corporations (foreign-related institutions). Banks exclude international banking facilities. The category of large domestic banks in the Federal Reserve's weekly H.8 statistical release, "Assets and Liabilities of Commercial Banks in the United States," includes about forty of the largest domestic commercial banks, which together account for about 55 percent of assets held by all domestic banks. Domestic institutions not included in the large bank category compose the small bank category. Large domestic banks constitute a universe; data for small domestic banks and foreign-related institutions are estimates based on weekly samples and on quarter-end condition reports. Data are adjusted for breaks caused by reclassifications of assets and liabilities. The data for large and small domestic banks are also adjusted to remove the estimated effects of mergers between these two groups. For further details about the H.8 release, see www.federalreserve.gov/releases $/ \mathrm{h} 8$.
1. Real value of C\&I loans at banks, 1988-2003

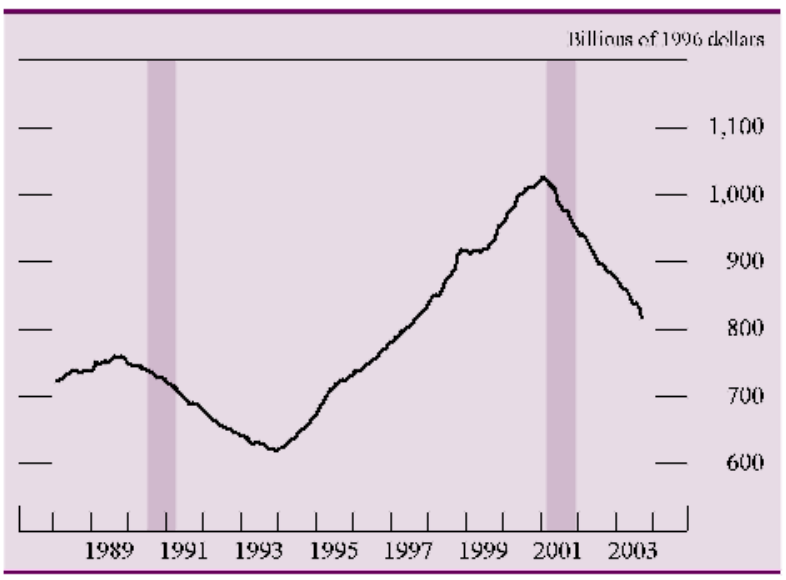

NoTE. The data are monthly through October 2003 and are deflated by the price deflator for business-sector output $(1996=100)$. Here and in the following charts, shaded bars represent recessions as dated by the National Bureau of Economic Research. See also text note 2.

SOURGE. Federal Reserve Board, Statistical Release H.8, "Assets and Liabilities of Commercial Banks in the United States" (www.federalreserve. gov/releases/h8); Bureau of Economic Analysis.

this article focuses on business lending at domestic institutions, for two reasons. ${ }^{3}$ First, U.S. branches and

3. For further discussion of foreign banking organizations, see Allen N. Berger and David C. Smith, "Global Integration in the Banking Industry," Federal Reserve Bulletin, vol. 89 (November 2003), pp. 451-60.

2. Real growth rate of C\&I loans, by type of bank, 1988-2003

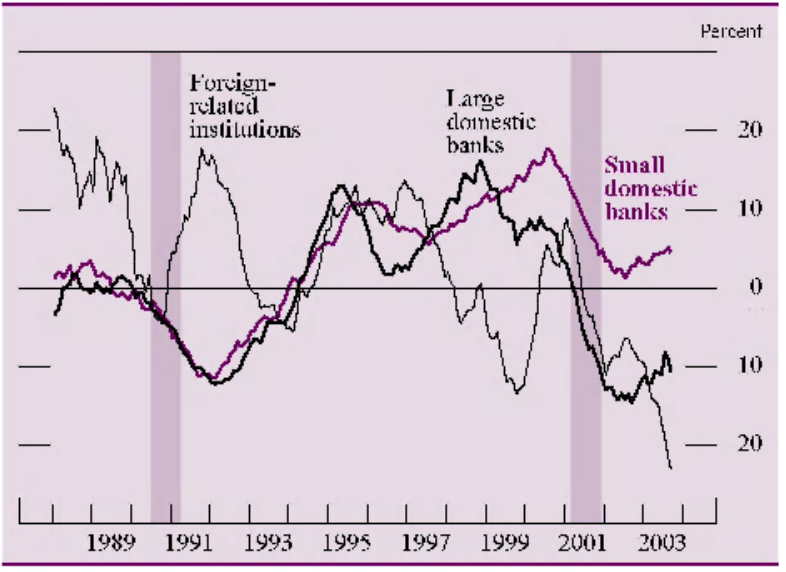

NoTE. The data are monthly through October 2003; change is for twelve months. See also text note 2 . 
agencies compete most directly with large domestic banks for customers in the C\&I loan market. Therefore, the factors that depressed lending at large domestic banks over the past three years likely exerted a similar influence on foreign institutions. Second, the analysis of business lending at branches and agencies of foreign banks is complicated by the pronounced downward trend in their share of C\&I loans (chart 3). The reduced intermediation by foreign institutions since the mid-1990s has been due largely to a sharp pullback in business lending by the U.S. branches and agencies of Japanese banks, many of which are saddled with a substantial volume of nonperforming loans and face significant pressures on their capital positions.

The divergence between large and small domestic commercial banks in the growth of business loans over the past three years appears to stem from the combined effects of weakness in demand for C\&I loans from larger businesses and a relatively greater tightening of supply conditions at large banks. Although sharp cutbacks in capital spending and steep inventory runoffs since early 2001 have significantly reduced demand for C\&I loans from borrowers of all sizes, the decline in loan demand from larger corporate borrowers-which maintain lending relationships mainly with large banks - has been especially pronounced. The reduction in demand for business loans from larger firms has been exacerbated by an evaporation of merger and acquisition (M\&A) activity and a substitution of bond finance for bank loans on firms' balance sheets. On the supply side, large commercial banks tightened their credit standards and began imposing more stringent loan terms well before the recent economic downturn.

3. Share of C\&I loans held by U.S. branches and agencies of foreign banks, 1988-2003

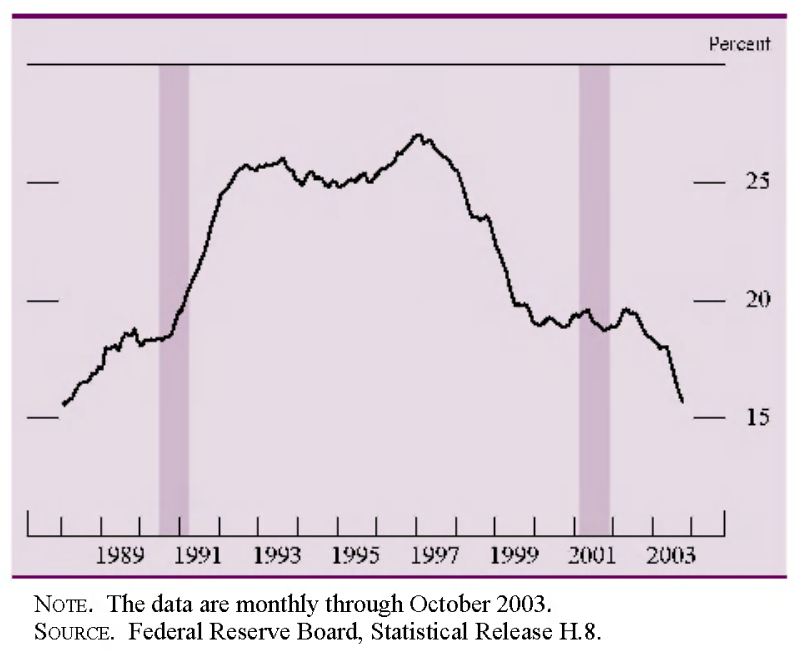

These institutions further tightened their commercial credit policies as the economy slipped into recession and as a substantial deterioration in the credit quality of their borrowers pushed delinquencies and chargeoffs on C\&I loans to high levels.

The move toward a more stringent lending posture by domestic commercial banks before and during the recent economic downturn, although partly cyclical, has also been influenced by a reassessment of the risk-return tradeoff inherent in C\&I lending, especially relative to the lax lending atmosphere of the mid-1990s. These structural changes in the way commercial banks price and allocate certain forms of business credit likely represent the cumulative effect of significant institutional developments in the C\&I loan market since the late 1980s. In large part, these developments have arisen from the increased participation of nonbank financial institutions in the syndicated loan market, which in turn has contributed importantly to the growth of the secondary loan market and of leveraged lending - that is, lending to large below-investment-grade borrowers. To the extent that these markets are almost exclusively provinces of large financial institutions, the reassessment of the attractiveness of syndicated and some forms of traditional C\&I lending has disproportionately affected large commercial banks and has contributed to the divergence in business lending patterns between large and small domestic banks.

In contrast to C\&I loans, other forms of credit at domestic commercial banks have flowed relatively freely during the past several years. Although the growth of real bank credit declined notably during the 2001 recession, it did not fall as low as it did in the early $1990 \mathrm{~s}$, and its recovery has been much

\section{Change in real value of bank credit, 1988-2003}

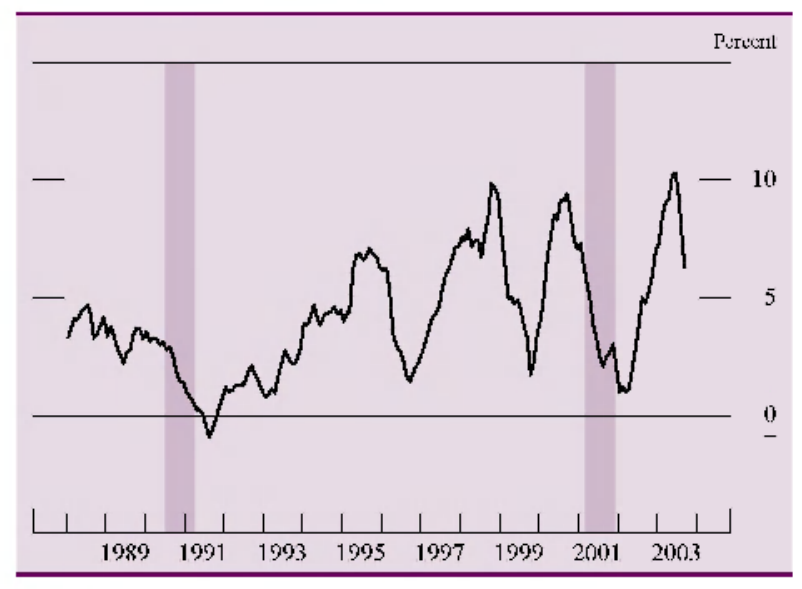

NoTE. The data are monthly through October 2003 and are deflated by the GDP price deflator $(1996=100)$; change is for twelve months. SOURCE. Federal Reserve Board, Statistical Release H.8. 


\section{Measures of: bank profitability, 1985-2003:Q3}

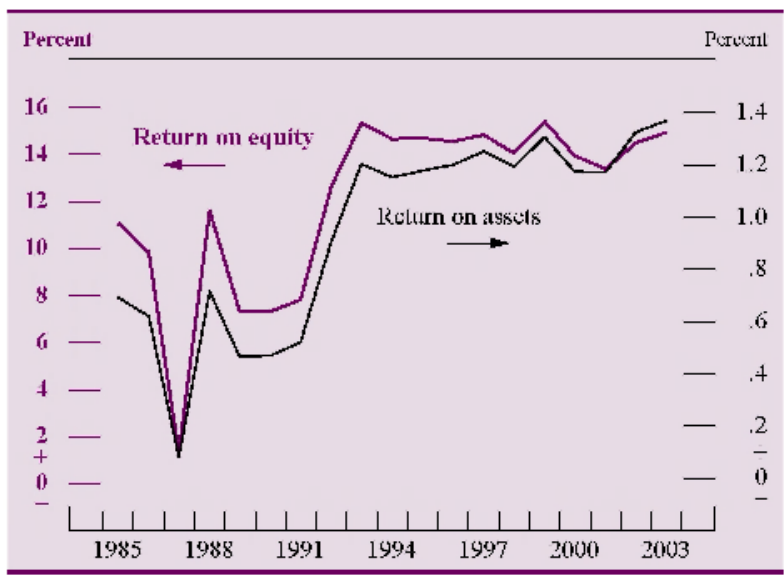

NotE. The return on equity and the return on assets are annual; for 2003 , they are estimates based on seasonally adjusted data through 2003:Q3.

SOURCE. Call Report.

brisker (chart 4). In this cycle, bank credit has been buoyed by a substantial expansion of banks' real estate portfolios and holdings of mortgage-backed securities. At the same time, the growth of consumer spending has held up well, allowing commercial banks to continue increasing their holdings of credit card and other types of consumer loans. Partly as a result of the robust lending to houscholds, a resilient commercial real estate loan market, and growth in

\section{Regulatory capital ratios, 1990-2003:Q3}

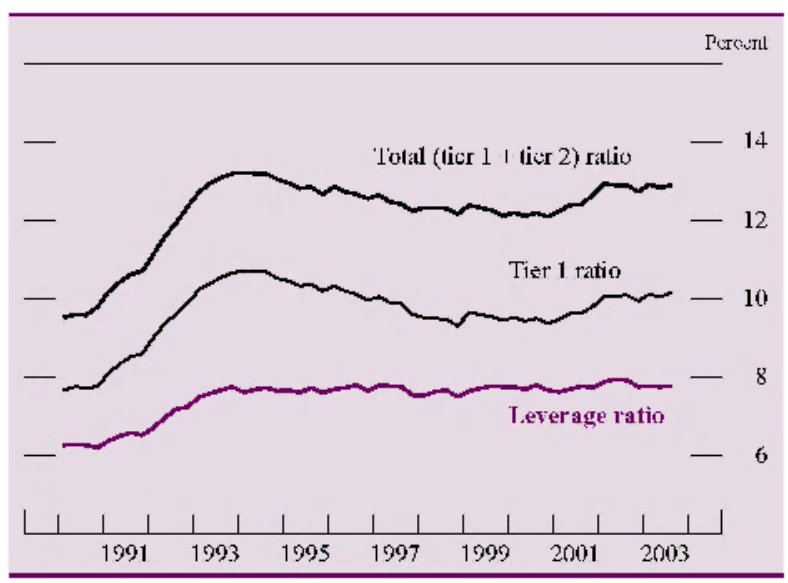

NoTE. Regulatory capital ratios are seasonally adjusted. Tier 1 capital consists primarily of common equity (excluding intangible assets such as goodwill and net unrealized gains on investment account securities classified as available for sale) and certain perpetual preferred stock. Tier 2 capital consists primarily of subordinated debt, preferred stock not included in tier 1 capital, and loan-loss reserves. Total capital is tier 1 plus tier 2 capital. Risk-weighted assets are calculated by multiplying the amount of assets and the credit-equivalent amount of off-balance-sheet items (an estimate of the potential credit exposure posed by the item) by the risk weight for each category. The risk weights rise from 0 to 1 as the credit risk of the assets increases. The leverage ratio is the ratio of tier 1 capital to average tangible assets. Tangible assets are equal to total assets less assets excluded from common equity in the calculation of tier 1 capital.

SOURCE. Call Report. fee-generating lines of business, commercial banks have remained highly profitable despite an increase in loan losses, especially on C\&I loans (chart 5). Thus, in sharp contrast to the circumstances of the early $1990 \mathrm{~s}$ and despite some restrictions on the supply of business credit from large domestic commercial banks, the banking sector has remained well capitalized and is poised to support growth in demand for business loans (chart 6).

\section{FACTORS AFFECTING THE DEMAND FOR C\&I LOANS}

Between 1997 and 2000, spending on capital equipment by businesses boomed. As a result, the gap between capital expenditures and internally generated funds for the nonfarm nonfinancial corporate sector-relative to the output of the sector-shot up from 1, 1,2 percent at the end of 1997 to more than 4 percent at its peak in 2000 (chart 7). Concomitantly, the bull market in equities supported a frenzied pace of mergers and acquisitions, for many of which commercial banks provided initial financing. Not surprisingly, the expansion of C\&I loans at both large and small domestic commercial banks reached doubledigit annual rates over this period.

The strong pace of corporate spending, however, proved unsustainable, and companies sharply reduced their capital expenditures as the economy entered recession in March 2001. Firms also responded quickly to falling sales by curtailing production to

7. Financing gap at nonfarm nonfinancial corporations, 1988-2003:Q2

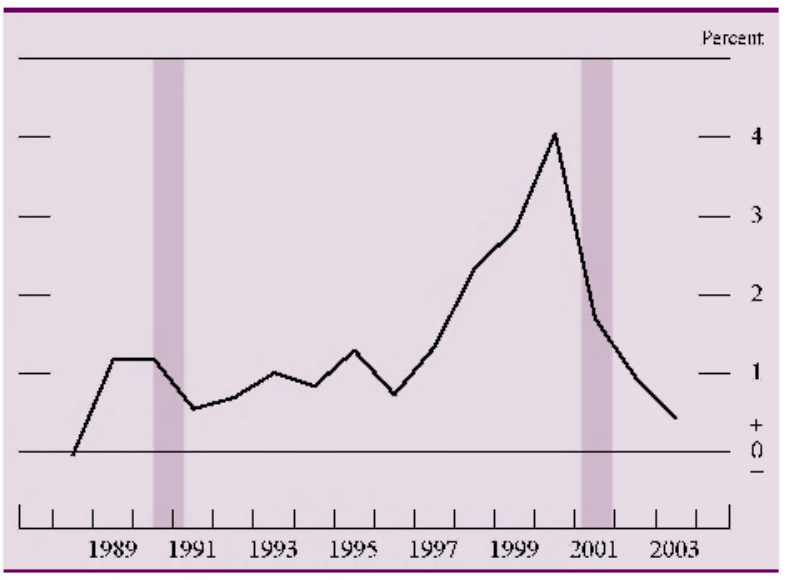

NoTE. The data are annual through 2002; for 2003, they are estimates based on data through 2003:Q2. The financing gap is the difference between capital expenditures and internally generated funds, expressed as a fraction of output by the nonfarm nonfinancial corporate sector.

SOURCE. Federal Reserve Board, Statistical Release Z.1, "Flow of Funds Accounts of the United States," table L.101 (www.federalreserve.gov/ releases $/ z 1$ ). 
avoid an accumulation of inventories and associated financing costs. Compounding the reduction in demand for business credit, especially at large banks, was the steep drop in equity prices, which largely short-circuited M\&A activity. With capital spending and merger activity dropping off, extensions of loans slumped. A sluggish recovery in an uncertain economic climate did little to lift business fixed investment in 2002, and businesses lacked an incentive to rebuild depleted inventory stocks. Although capital spending has picked up in 2003, a rebound in corporate profits, partly reflecting robust gains in productivity, has limited firms' needs for external funds. As a result, the financing gap has remained at its preboom level. Credit demands to finance mergers and acquisitions have also remained weak despite a substantial rise in equity prices in 2003.

The cyclical fluctuations in demand for C\&I loans are evident in the responses to the Federal Reserve's Senior Loan Officer Opinion Survey on Bank Lending Practices (informally, the bank lending practices survey, or BLPS). ${ }^{4}$ According to the survey, the demand for C\&I loans from small firms, as well as middle-market and large firms, has weakened continuously since the middle of 2000 (chart 8). Moreover, the reported weakening in demand has persisted considerably longer after the official end of the most recent recession than it did after the cyclical trough in March 1991.

4. For text of questions and tallies of responses in surveys conducted since the beginning of 1997, see www.federalreserve.gov/ boarddoes/SnLoanSurvey.

8. Net percentage of banks reporting stronger demand for C\&I loans, by size of borrower, 1991:Q4-2003:Q4

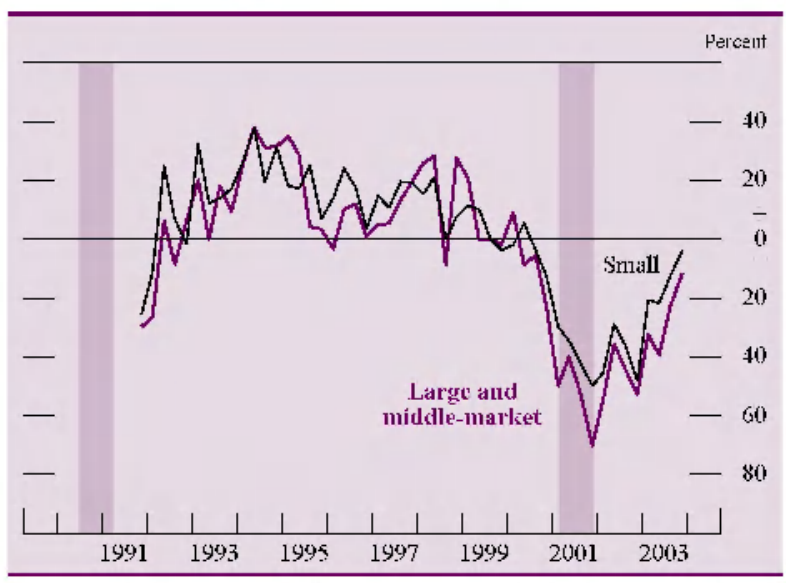

NoTE. The data are quarterly. Net percentage is the percentage of banks reporting stronger demand less the percentage reporting the opposite. The definition for firm size sugggested for, and generally used by, survey repondents is that large and middle-market firms have sales of more than $\$ 50$ million.

SOURCE. Federal Reserve Board, Senior Loan Officer Opinion Survey on Bank Lending Practices.
9. Change in real spending on equipment and software and the net percentage of banks reporting stronger demand for $C \& I$ loans as a result of increased capital expenditures, 1997:Q1-2003:Q4

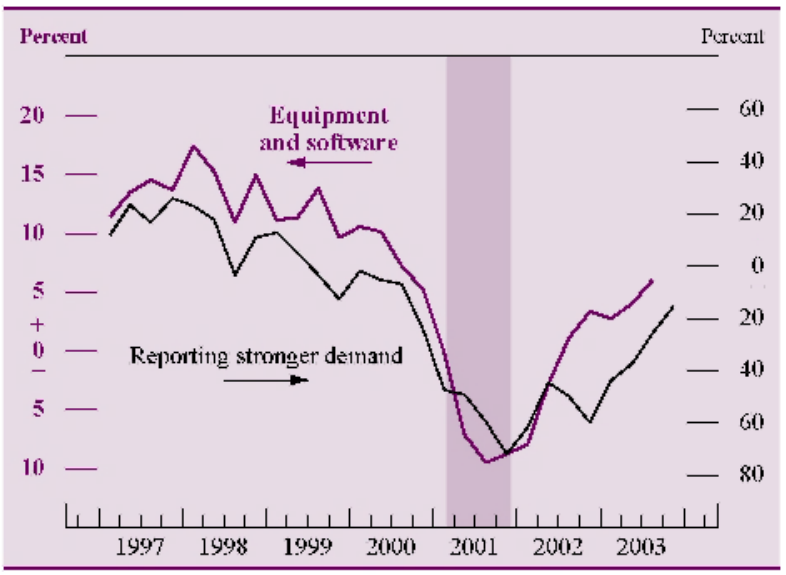

NotE. The data are quarterly; change is for four quarters. Net percentage is the percentage of banks reporting stronger demand because of increased capital expenditures less the percentage reporting weaker demand because of reduced capital expenditures.

SouRces. Federal Reserve Board, Senior Loan Officer Opinion Survey on Bank Lending Practices; Bureau of Economic Analysis.

A detailed look at the fluctuations in demand for C\&I loans is possible from 1997 onward because respondents to the BLPS have been queried regularly since then about the factors affecting demand for business loans at their banks. Consistent with the retrenchment in investment spending, the most cited reason for the reported decline in demand at respondent banks since the end of 2000 has been a decrease in their customers' capital expenditures (chart 9).

10. Change in real nonfarm inventories and the net percentage of banks reporting stronger demand for C\&I loans as a result of increased inventory financing needs, 1997:Q4-2003:Q4

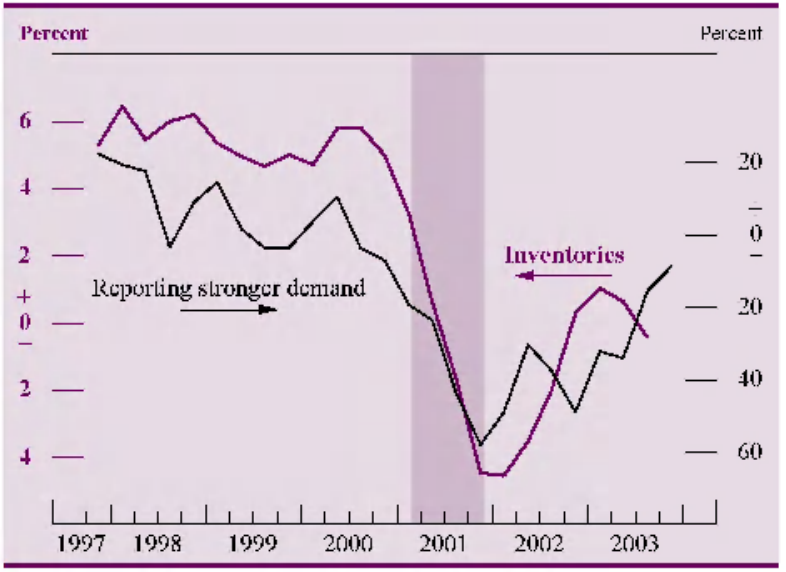

NoTE. The data are quarterly; change is for four quarters. Net percentage is the percentage of banks reporting stronger demand because of increased inventory financing needs less the percentage reporting weaker demand because ofireduced inventory financing needs.

SOURCE. See source note to chart 9. 
11. Net equity retirements by domestic corporations and the net percentage of large banks reporting stronger demand for C\&I loans as a result of increased M\&A financing needs, 1998:Q1-2003:Q4

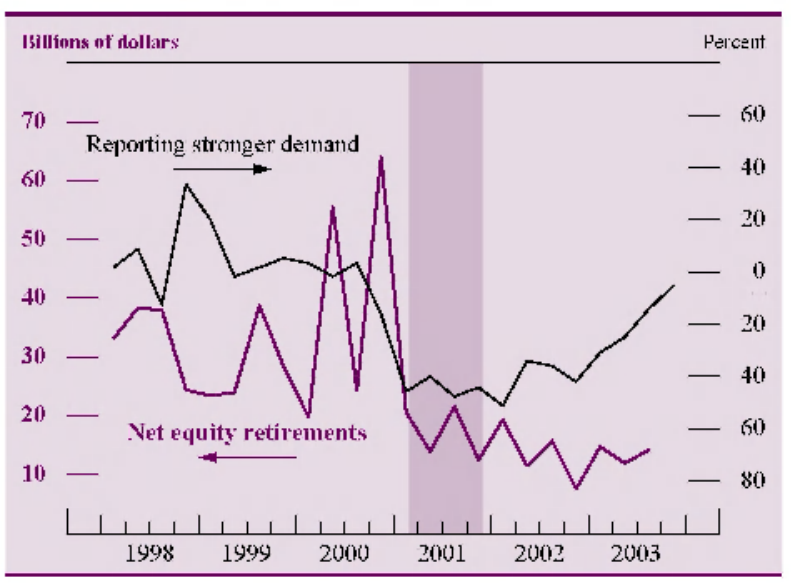

NoTE. The data are quarterly; change is for four quarters. In 1998, large banks were those with assets of more than \$15 billion; since 1999, large banks have been those with assets of more than \$20 billion. Net percentage is the percentage of banks reporting stronger demand because of increased M\&A financing needs less the percentage reporting weaker demand because of reduced M\&A financing needs.

SOURCES. Federal Reserve Board, Senior Loan Officer Opinion Survey on Bank Lending Practices; Securities Data Company.

Similarly, the sharp inventory runoff since early 2001 is closely correlated with the net percentage of survey respondents that reported a reduction in inventoryrelated financing needs (chart 10). On average, about half the largest banks on the survey panel-the institutions most likely to fund large M\&A dealsindicated that their customers' needs for this type of financing had decreased over the past three years (chart 11). These responses correspond reasonably well with movements in retired equity of domestic nonfinancial corporations-a proxy for M\&A

12. Major components of net business financing, 1992-2003

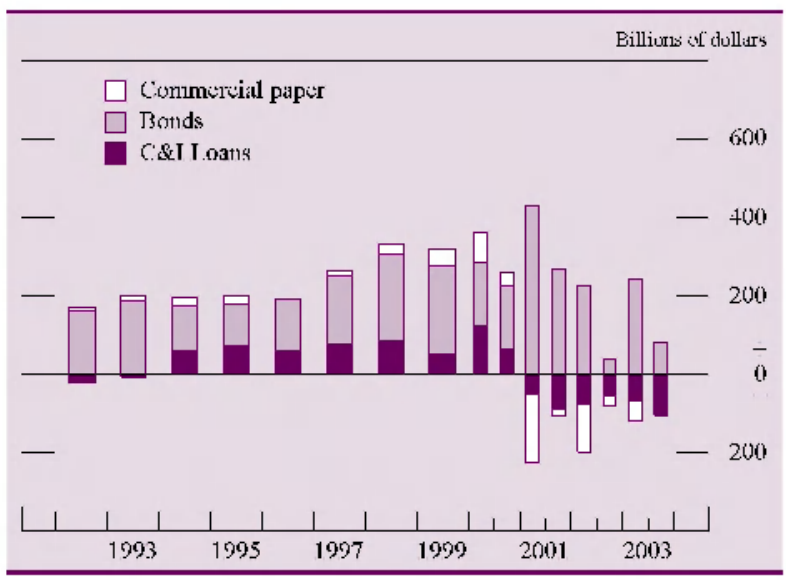

NOTE. Beginning in 2000 , the data are semi-annual and are at seasonally adjusted annual rates. The data for $2003: \mathrm{H} 2$ are projected from data through October. activity - and support the view that large banks experienced a relatively bigger drop in C\&I loan demand than did small banks.

Another factor contributing to the weakness in demand for business loans since 2001 has been heavy

corporate bond issuance, as firms have substituted longer-term debt for short-term debt obligations, such as C\&I loans and commercial paper (chart 12). The runoff in commercial paper significantly reduced the demand for commercial paper backup lines of credit, which are provided mainly by large commercial banks. ${ }^{5}$ Accordingly, firms' preference for longerterm, public-market debt partly reduced the unused lines of credit at commercial banks (chart 13).

Firms' decisions to lengthen the average maturity of their outstanding debt was importantly influenced by substantial declines in longer-term interest rates in 2001 and 2002 (chart 14). In addition, ratings agencies and investors reportedly pressured some large corporations to strengthen their balance sheets by reducing their reliance on short-term debt. The restructuring of firms' balance sheets is reflected in the sharp drop in the ratio of short-term debt to total debt outstanding from almost 40 percent in 1999 to about 30 percent in the second quarter of 2003 (chart 15).

5. In assigning a credit rating to an issuer of commercial paper, public rating agencies take into account the borrower's general credit quality as well as the borrower's ability to obtain from a financial institution a line of credit that can be used to retire maturing paper in the event that it cannot be rolled over. Firms have a strong incentive to issue highly rated commercial paper because money market mutual funds-the primary holders of these securities-can hold only a limited amount of lower-rated commercial paper.

13. Change in the amount of real unused business credit lines at U.S. commercial banks, 1991:Q2-2003:Q3

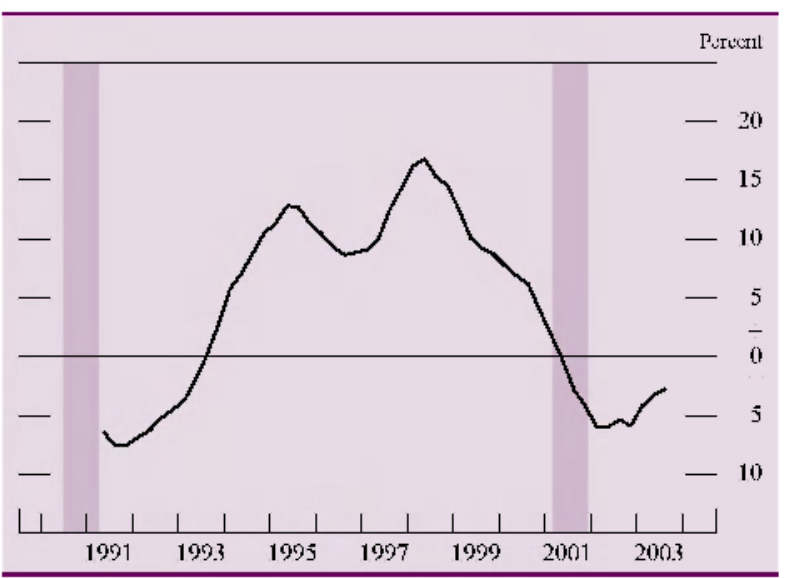

NoTE. The data are quarterly and are deflated by the price deflator for business-sector output $(1996=100)$; change is for four quarters. SOURCE. Call Report. 
14. Corporate bond yields, by rating, 1989-2003

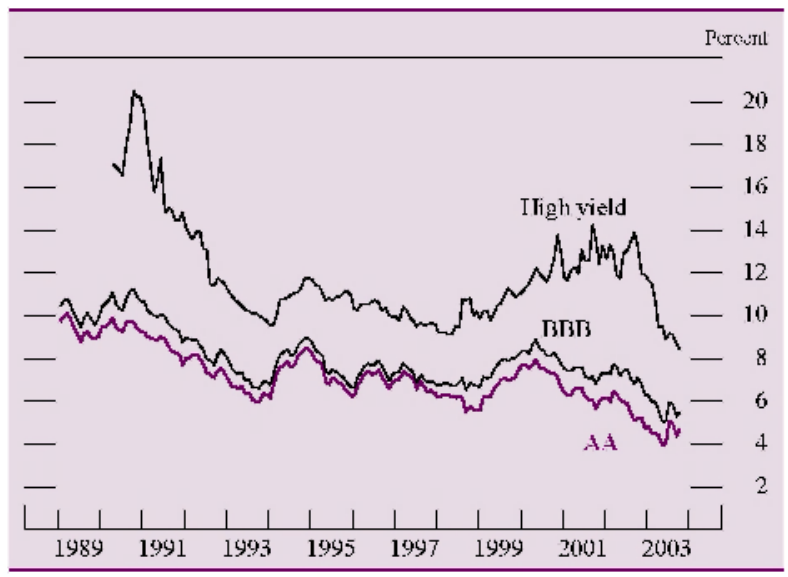

Note. The data are monthly averages through October 2003. The AA and $B B B$ rates are calculated from bonds in the Merrill Lynch AA index and $B B B$ index, respectively, with seven to ten years of maturity remaining. The high-yield rate is the yield on the Merrill Lynch 175 high-yield index.

Commercial real estate lending may also have helped reduce demand for C\&I loans. Over the past several years, nonresidential construction activity has decelerated significantly, office vacancy rates have increased, and commercial rents have declined. Nonetheless, this type of lending has been surprisingly well maintained during the recent cycle, and delinquency and charge-off rates on commercial real estate loans have risen only moderately from very low levels. The continued growth of commercial real estate loans may be due to efforts by some firms to lock in low long-term interest rates by substituting fixed-rate loans backed by real estate for traditional business loans, which typically have shorter maturities and carry floating rates. Indeed, according to the

15. Ratio of: short-term debt to total credit-market debt for nonfarm nonfinancial corporations, 1988-2003:Q2

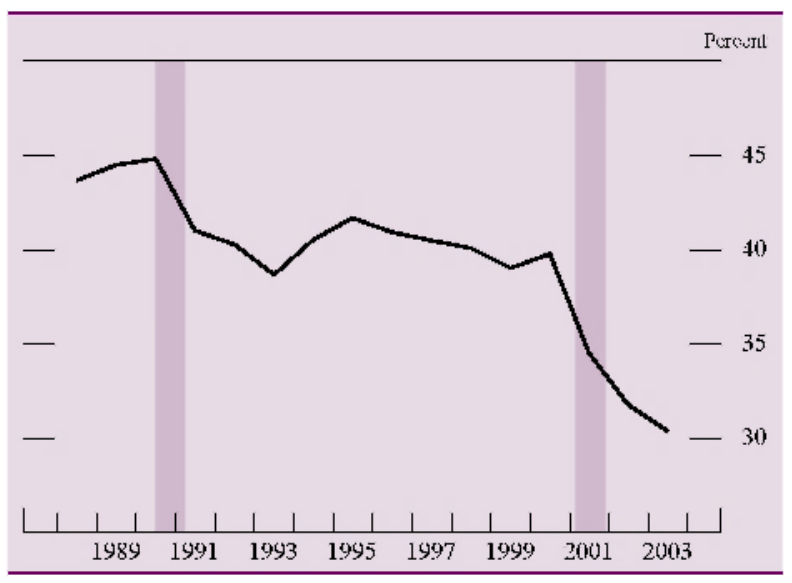

NoTE. The data are annual through 2002; for 2003, they are estimates based on data from 2003:Q2.

SOURCE. Federal Reserve Board, Statistical Release Z.1, "Flow of Funds Accounts of the United States," table L.102 (www.federalreserve.gov/ releases $/ \mathbf{z} 1$ ).
August 2002 BLPS, one-fourth of banks with assets of less than $\$ 20$ billion-institutions that in recent years have experienced particularly strong growth in commercial real estate lending-reported that the volume of their commercial real estate loans that were used for commercial and industrial purposes (rather than the acquisition or improvement of real estate) had increased over the previous year. A small net percentage of those banks reported in the October 2003 BLPS that they had continued to experience an increase in demand for commercial real estate loans for which the proceeds were earmarked for commercial and industrial purposes.

\section{FACTORS AFFECTING THE SUPPLY OF. C\&I LOANS}

The recent runoff in C\&I loans appears to be related not only to weaker demand but also to tighter loan supply conditions. The effects from tighter supply, however, do not seem to be as significant as they were in the early 1990s. Many large commercial banks entered the previous decade with low levels of equity capital, partly because of considerable losses stemming from the Latin American debt crisis of the mid-1980s. The collapse of the commercial real estate market in the early 1990s also impaired banks' profitability and further eroded their capital bases. At the same time, commercial banks were coming under significant pressure from bank regulators and investors to rebuild their capital, pressure that was intensified by the adoption of the Basel standards for riskbased capital. Because commercial banks are not required to hold risk-based capital against U.S. Treasury securities, the attractiveness of these investments rose relative to that of loans. Under these circumstances, commercial banks became increasingly reluctant to lend to households or businesses. The inhospitable business-borrowing environment of the early 1990s is reflected in the significant net percentages of BLPS respondents that reported a tightening of lending standards in surveys conducted during that period (chart 16). The period was also marked by weak demand for credit, as households and businesses moved to strengthen their own balance sheets after heavy borrowing during the late 1980s.

As the economy recovered from the 1990-91 recession, borrowers and banks rebuilt their balance sheets, and commercial banks expanded their lending. The industry's asset quality and profitability improved, lifting banks' regulatory capital ratios significantly above regulatory minimums. Partly because of the brighter economic outlook, higher 
16. Net percentage of banks that reported tightening standards for C\&I loans, by size ol borrower, 1990:Q2-2003:Q4

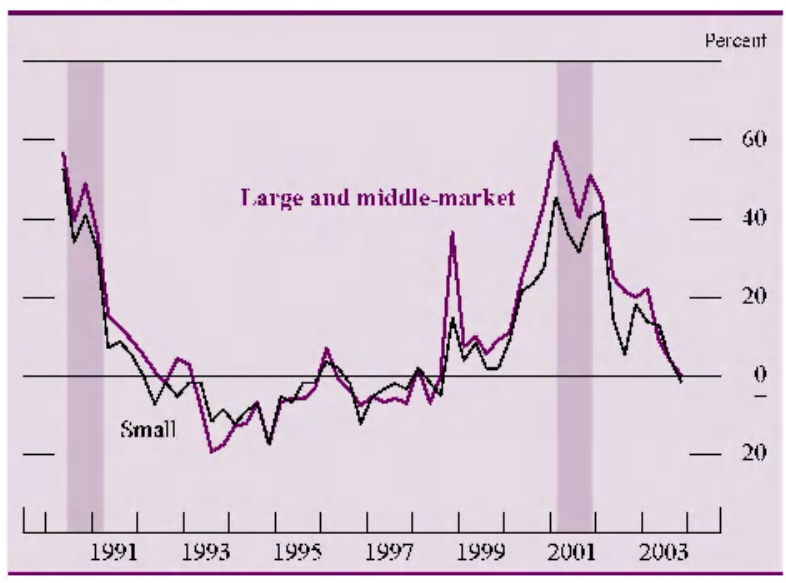

NoTe. 'The data are cuaterly. - Vit percenlaye is the percentage of banks that reported a tightening of standards less the percentage that reported an casing. The disfinition for fim sizi suggesked for; and gencrally used by, survey respondents is that lare and middle-market firms have sales of more than $\$ 50$ million.

Sol.KC.F. Tederal Resenve Board, Senior I oat Officer Opinion Survey on Bamk Linding l'raclicis.

capital levels, and better asset quality, commercial banks by 1993 had begun easing their lending standards and accepting lower spreads on C\&I loans and credit lines. Banks also reported easing nonprice lending terms, such as loan covenants and collateral requirements, which are designed to protect banks if a borrower becomes impaired before the loan is repaid. Over the same period, the net percentage of small firms reporting that credit was harder to obtain declined considerably, according to the Survey of

17. Net percentage of small businesses that reported more difficulty in obtaining credit, 1988-2003:Q3

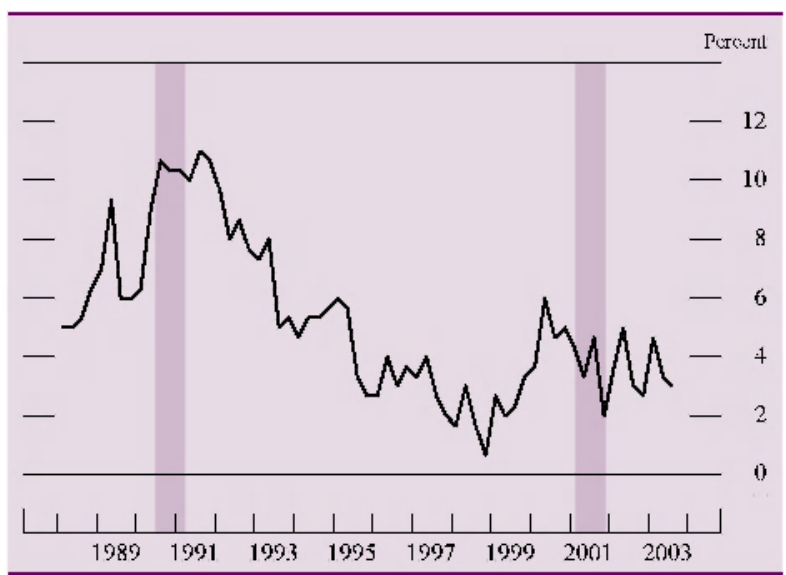

NoTE. The net percentage is defined as the number of borrowers that reported more difficulty in obtaining credit less the number that reported more ease in obtaining credit as a fraction of borrowers who sought credit during the previous three months.

Source. National Federation of Independent Business, Survey of Small Businesses.
Small Businesses conducted by the National Federation of Independent Business (chart 17).

Market commentary, as well as narrow credit spreads on corporate debt instruments, also suggested that lending conditions had become very favorable for business borrowers, especially as the economy began to accelerate over the latter half of the 1990s. By the middle of 1998, bank supervisors and examiners had become increasingly concerned about banks' lending practices, as evidenced by statements from the Federal Reserve and other bank regulatory agencies. One statement urged banks to "continue to focus on the strength of the credit-risk management process, not only under favorable conditions, but also under stressful circumstances." 6

The warnings of bank regulators took on a prophetic dimension in August 1998, when the Russian government announced a moratorium on servicing official short-term debt and devalued the ruble. The resulting shockwaves, exacerbated by difficulties at a prominent hedge fund, Long-Term Capital Management, led to turbulence in capital markets in the United States and elsewhere: Credit spreads ballooned, and liquidity deteriorated. Although the U.S. economy remained strong and the Federal Open Market Committee eased monetary policy that fall in three increments of 25 basis points each, commercial banks nevertheless seemed to respond by reassessing the riskiness of their business lending. Abruptly reversing course, nearly half the respondents to the November 1998 BLPS indicated that they had tightened business lending standards and terms over the preceding three months, the highest net percentage that had reported doing so since early 1991. In addition, banks disproportionately imposed morestringent commercial lending standards on large and middle-market borrowers, which they had apparently started to perceive as riskier credits.

Although the net proportion of banks that reported tightening lending standards declined markedly in subsequent surveys, it remained positive, and other indicators also continued to suggest that the easy lending environment of the mid-1990s had come to an end. In late 1998, spreads on originations of new C\&I loans-measured relative to estimated bank funding costs-increased significantly, as reported in the Federal Reserve's quarterly Survey of Terms of Business Lending (STBL) (chart 18). The wider spreads evident in the STBL were mirrored in a substantial jump of spreads and fees on syndicated

6. The Federal Reserve's Division of Banking Supervision and Regulation sent to the banks that it supervises a letter on lending standards for commercial loans. See letter SR 98-18, www.federalreserve.gov/boarddocs/SRLETTERS/1998/SR9े818.htm. 
18. Spread on C\&I loans at domestic banks, 1997-2003:Q3

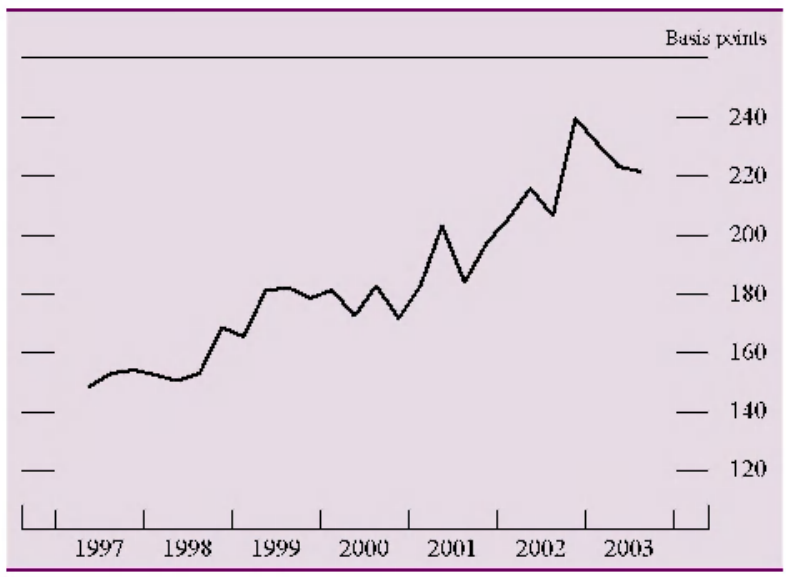

NoTE. Spread is the difference between the loan rate and the bank's funding cost, represented by a eurodollar or swap interest rate of comparable maturity.

SOURCE. Federal Reserve Board, Survey of Terms of Business Lending.

loans, particularly for weak-investment-grade and below-investment-grade borrowers, according to data collected by the Loan Pricing Corporation (LPC) (chart 19). Pricing of business loans and corporate bonds continued to hover in the new, elevated range even after the stock market resumed its upward march, the liquidity of the bond market improved, and the U.S. economy continued to perform as well as it had in decades.

Despite the tighter lending standards that banks put in place in late 1998 and the strong economic growth during 1999 and the first half of 2000, the delinquency rate on C\&I loans at large banks trended higher (chart 20). According to the January 2000 BLPS, the deterioration in business loan quality since

19. All-in drawn spreads on syndicated loans of maturity greater than one year, by rating of borrower, 1998-2003

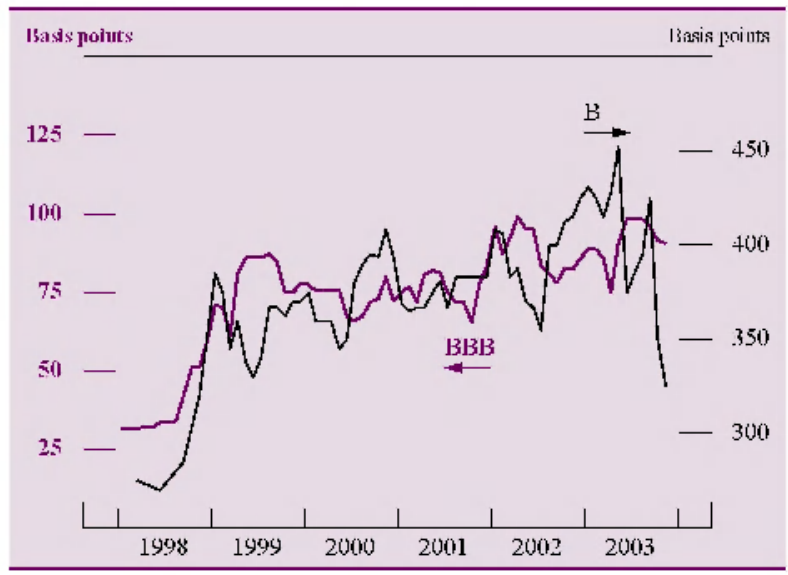

NOTE. Data are monthly through October 2003. All-in drawn spreads reflect the amount a lender will earn on a facility, considering all fees (except usage fees) and the libor spread, assuming the entire credit facility is drawn down.

SOURCE. Loan Pricing Corporation.
20. Delinquency and net charge-off rates on $\mathrm{C} \& \mathrm{I}$ loans at banks, by size of bank, 1988-2003:Q3

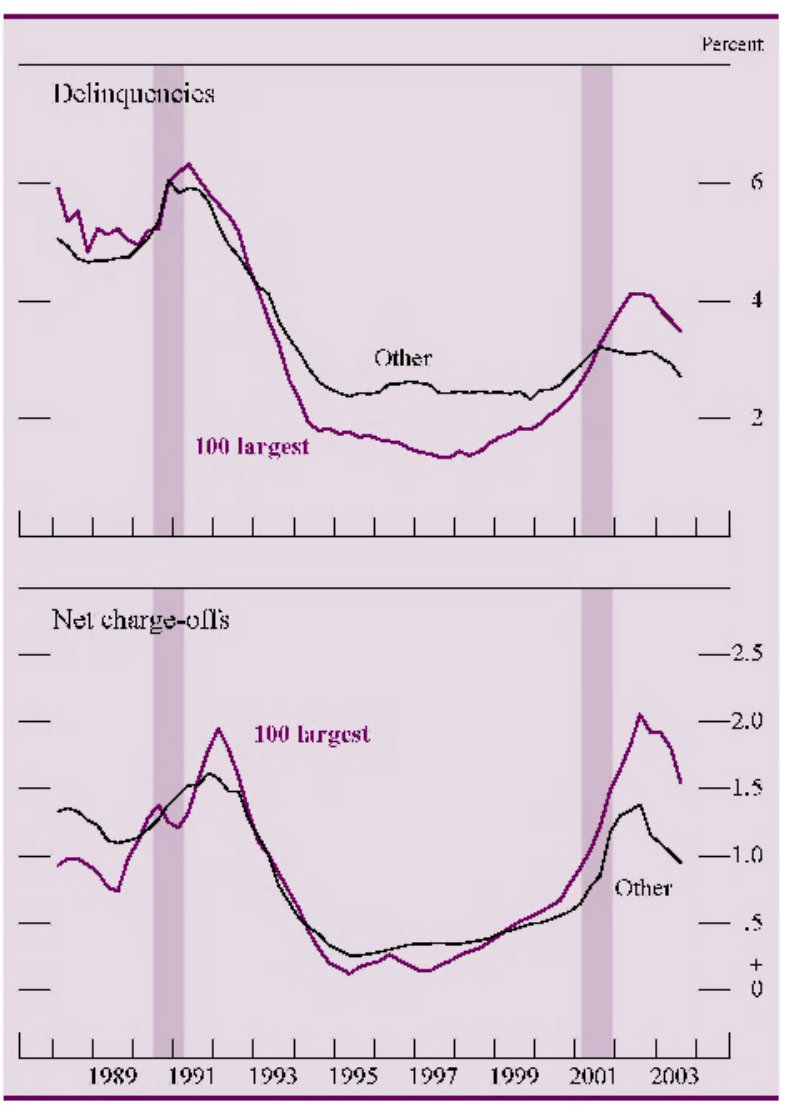

NoTE. The data are quarterly and seasonally adjusted. Delinquent loans are loans that are not accruing interest and those that are accruing interest but are more than thirty days past due. The delinquency rate is the end-of-period level of delinquent loans divided by the end-of-period level of outstanding loans. The net charge-off rate is the annualized amount of charge-offs over the period, net of recoveries, divided by the average level of outstanding loans over the period.

SOURCE. Call Reports.

1998 was due partly to the reversion of delinquency rates to a more-normal long-run level and to problems that had developed in some industries, particularly health care. But as the long bull market in stocks came to an end in spring 2000 and the economy began to show signs of slowing in the fall, delinquencies and charge-offs on C\&I loans at commercial banks accelerated. In light of this further deterioration in asset quality, the November 2000 BLPS asked banks about the extent to which the rise in delinquencies on C\&I loans had been in line with their expectations. Although the smaller banks indicated that they had largely anticipated the gradual increase in delinquency rates, a significant net percentage of larger banks on the survey panel reported that they were surprised by how much the quality of their C\&I loan portfolios had deteriorated over the previous two years. 
21. Net percentage of banks that reported higher premiums on riskier loans, by size of borrower, 1998:Q4-2003:Q4

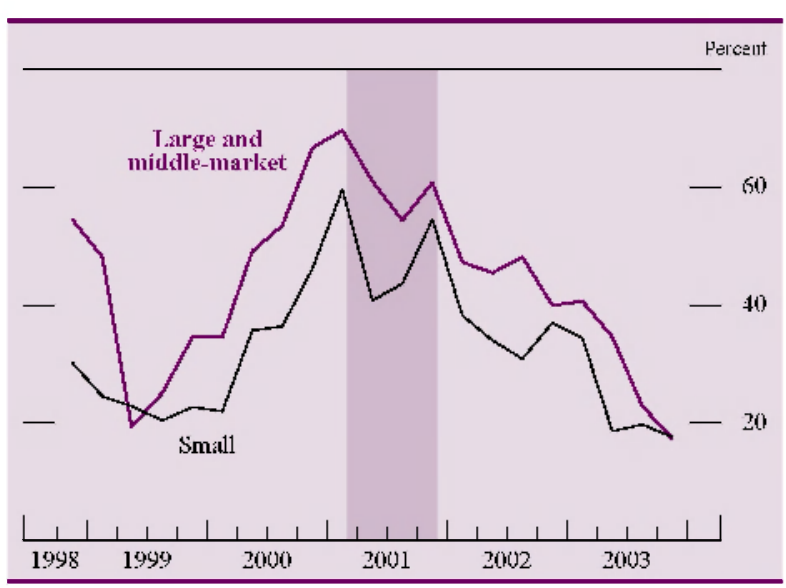

NoTE. The data are quarterly. Net percentage is the percentage of banks reporting higher premiums less the percentage reporting lower premiums. The definition for firm size suggested for, and generally used by, survey respondents is that large and middle-market firms have sales of more than $\$ 50$ million.

SOURCE. Federal Reserve Board, Senior Loan Officer Opinion Survey on Bank Lending Practices.

Responding to the worsening economic outlook and the deterioration in their asset quality, large net percentages of banks began reporting in late 2000 and in 2001 that they had further tightened lending standards and had imposed higher spreads and fees on C\&I loans for borrowers of all sizes. According to the respondents, the shift to a more-stringent lending posture also resulted from a reduced appetite for risk at their institutions, and nearly all banks reported that they had raised premiums charged on riskier C\&I loans, especially for large and middle-market firms

\section{Spread on C\&I loans at domestic banks, by} risk category of loan, 1997-2003:Q3

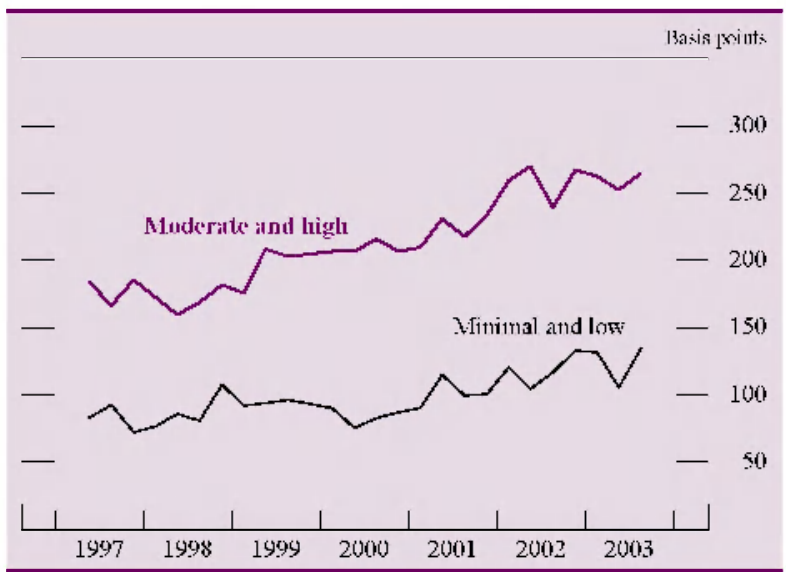

NoTE. Spread is the difference between the loan rate and the bank's funding cost, represented by a eurodollar or swap interest rate of comparable maturity. High-risk loans are those in risk categories acceptable and classified.

SOURCE. Federal Reserve Board, Survey of Terms of:Business Lending. (chart 21). Evidence from other data sources corroborated these qualitative responses from the BLPS: The spreads on loans in the riskier categories in the STBL increased steadily during 2001 and the first half of 2002, and they increased to a much greater extent than did the spreads on loans rated as having "low" or "minimal" risk (chart 22).

The terrorist attacks of September 11, 2001, dramatically raised the overall level of economic uncertainty. Corporate balance sheets had already deteriorated, and corporate profitability had declined sharply during the year, accelerating the pace of ratings downgrades and increasing defaults on corporate debt (chart 23). The collapse of Enron in early December 2001 and subsequent corporate accounting scandals cast doubt on the quality of auditing and corporate governance. And the possibility that more firms would be found to have engaged in questionable accounting practices exacerbated the general sense of

\section{Indicators of the credit quality of nonfinancial corporations, 1990-2003:Q3}

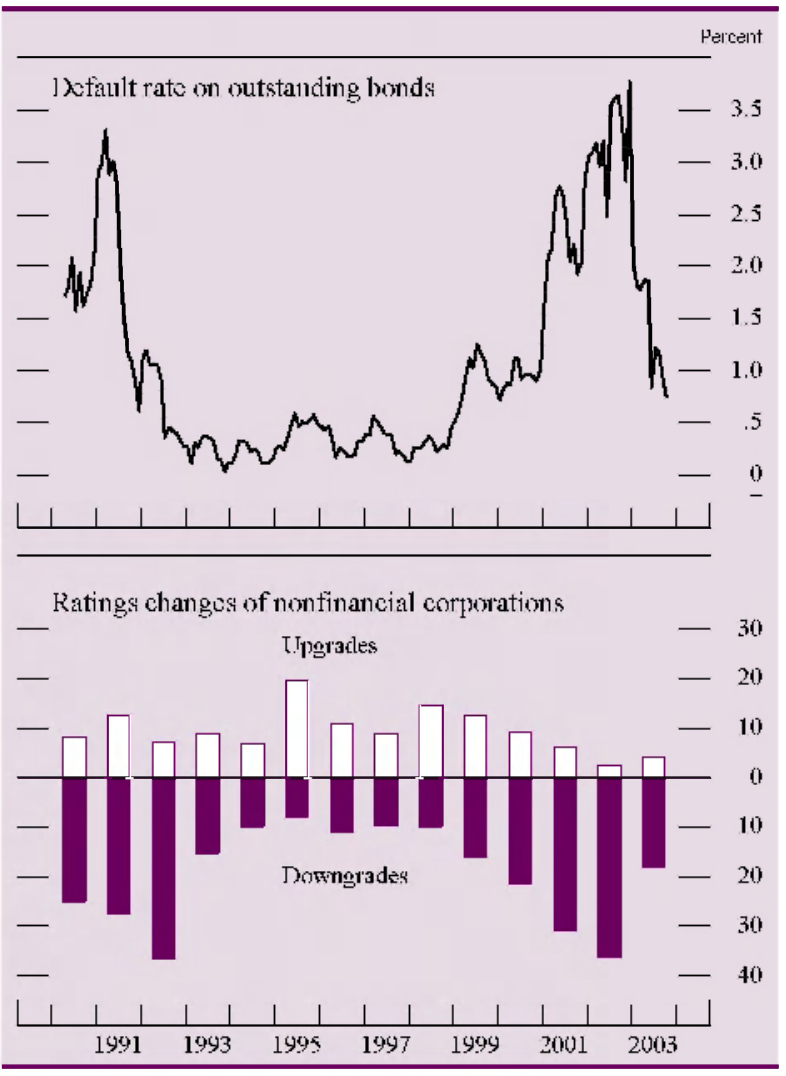

NoTE. The default rate is monthly and extends through October 2003 . The default rate for a given month is the face value of bonds that defaulted in the six months ending in that month divided by the face value of all bonds outstanding at the end of the calendar quarter immediately preceding the six-month period. The data on ratings changes are at an annual rate; for 2003 , they are the annualized values of monthly data through October. Debt upgrades and downgrades are expressed as percentages of the par values of all bonds outstanding.

SOURCE. Moody's Investors Service. 
uncertainty, especially for large business borrowers. However, small companies with straightforward business models were less likely to have used questionable accounting practices, and the NFIB's Survey of Small Businesses showed little evidence that small firms were facing significantly tighter credit conditions.

With the uncertain economic climate and corporate governance concerns, the net percentage of banks that reported tightening lending standards and terms in the BLPS remained elevated through the first half of 2002. In addition, responses to a question in the October 2001 BLPS indicated that almost one-half of banks had lowered their internal ratings on at least 5 percent of their rated C\&I loans over the previous three months, and several banks had downgraded more than 20 percent of these loans. These reported downgrades showed up in the STBL as banks assigned higher risk ratings to larger shares of newly originated loans: The share of STBL loans rated as high risk rose from about 30 percent in 2001 to almost 50 percent in the first quarter of 2003 (chart 24).

As with outstanding business loans, commercial banks have also moved to limit their exposure to committed lines of credit since the middle of 1998 . A large portion of these loan commitments have traditionally been extended to large, investment-grade corporate borrowers to support their commercial paper programs in the event of a temporary distuption in the market for commercial paper. Accordingly, banks typically viewed the lines as unlikely to be drawn down for purposes other than weathering a general liquidity squeeze. Nevertheless, backup lines

\section{Distribution of C\&I loan volume at domestic banks,} by risk category of loan, 1998-2003:Q3

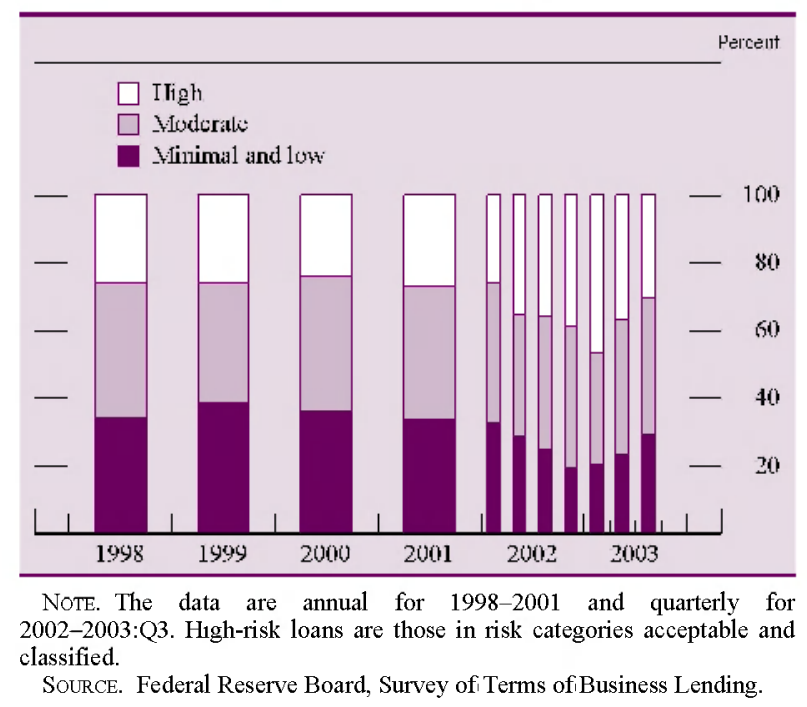

for commercial paper carry the possibility that a bank will end up as the "lender of last resort" for a company shut out of the commercial paper market because of a rapid deterioration in its own creditworthiness. To safeguard against such an occurrence, credit lines usually include covenants that, in theory, are designed to prevent a drawdown by a company that is experiencing financial distress. This possibility was generally considered remote, especially because, before the past few years, issuers on the upper rungs of the investment-grade ladder had rarely succumbed to sudden default.

Believing that commercial paper backup lines of credit were unlikely to be drawn down and that, even if drawn, they were unlikely to result in a loss, many large banks reportedly offered backup lines to some borrowers at very favorable terms. The first of these beliefs was challenged amid the financial market turmoil in the early fall of 1998 , when interest rate spreads in the commercial paper markets rose substantially. Rather than issuing commercial paper in those circumstances, a few companies turned to their banks and drew down their revolving credit lines, which at the time offered significantly more-attractive terms than those available in the commercial paper market. Because of these unanticipated draws, banks reduced the size and increased the costs of the lines that they were offering to their large business customers and reassessed the conditions under which the funds could be drawn (chart 25).

The spate of defaults by highly rated corporate borrowers during the recent economic slowdown raised questions about banks' second assumption regarding the likelihood and size of potential losses in investment-grade lending. ${ }^{7}$ Indeed, even at the time of the May 2001 BLPS, large percentages of banks reportedly had tightened their lending standards over the previous year on commercial paper backup lines, especially for firms with weaker commercial paper credit ratings. More than half the respondents indicated that they had begun charging higher up-front fees on backup lines and that they had increased the spreads that firms would pay if the lines were drawn. In addition, three-fourths of the domestic banks reported that commercial paper backup lines were unprofitable on a standalone basis but that firms used the bank to provide other services - such as cash management - that made the overall relation-

7. For example, WorldCom drew down about $\$ 2.5$ billion in bank lines just before revealing in June 2002 that it had substantially overstated its earnings; the company filed for bankruptcy the next month. Banks holding these lines, however, invoked covenants in the loan agreements that prevented WorldCom from drawing down the remainder of its reported $\$ 8$ billion in credit lines. 
25. Net pereenlage ol banks that reported lightening selected terms on eredit lines, by size of borrower. 1996:Q2-2003:Q4

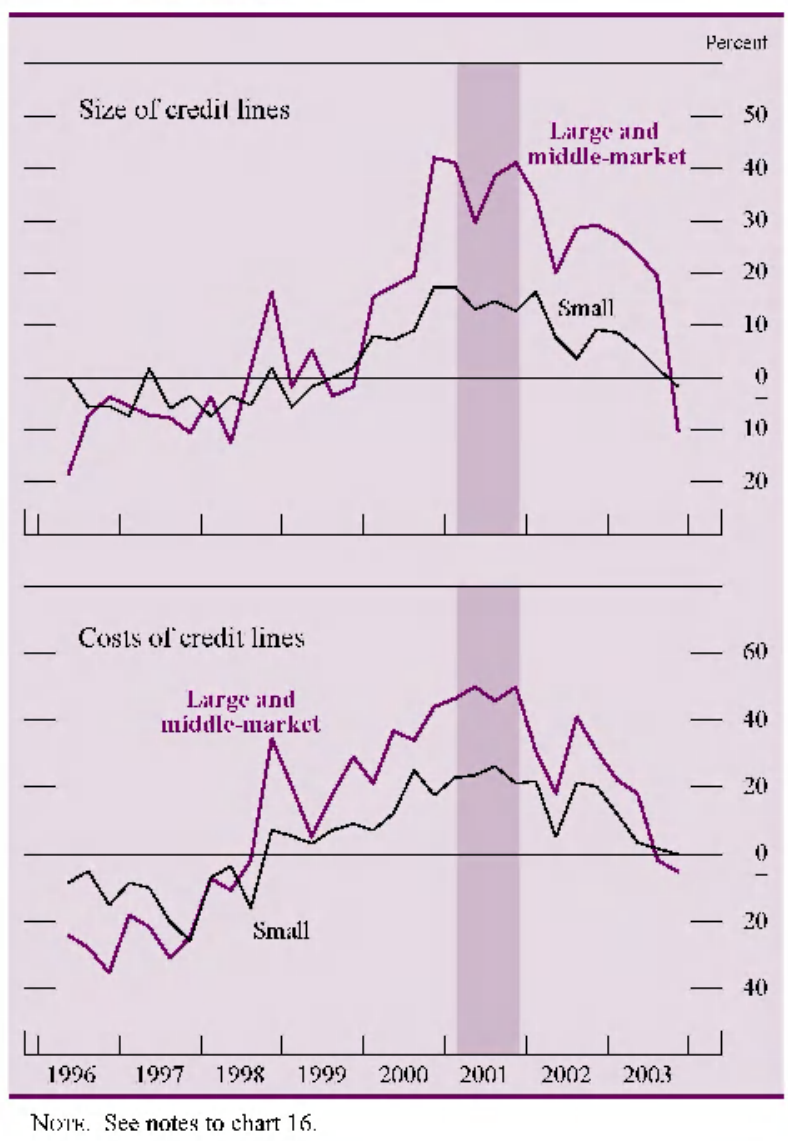

ship profitable for the bank. Banks also noted that they had moved to limit their risk by reducing the size of the loan commitments they were willing to offer, especially for lower-rated issuers of commercial paper. Not surprisingly, respondents indicated that they had tightened standards and terms on credit lines because they were increasingly concerned about the possible deterioration in the credit quality of issuers and because they perceived a higher probability that the lines would be drawn. ${ }^{8}$

8. Over the past two years, asset-backed commercial paper ( $A B C P$ ) issued by ABCP conduits administered by domestic commercial banks declined, after increasing in 2000 and 2001. The decline in ABCP conduits may have reflected not only reduced issuance of $A B C P$ because of iborrowers' preference for longer-term debt but also banks' uncertainty about the accounting treatment of securitized assets. On January 17, 2003, the Financial Accounting Standards Board released Interpretation 46, "Consolidation of Variable Interest Entities" (FIN 46), a rule that stipulates the accounting treatment for certain structured finance vehicles, including ABCP conduits. FIN 46 raised the possibility that commercial banks would have to consolidate on their balance sheets the assets and liabilities of the ABCP conduits that they sponsored, an action that would require banks to set aside additional regulatory capital. FIN 46 is now slated for adoption for

\section{STRUCTURAL DEVELOPMENTS IN THE MARKET} FOR C\&I LOANS

Over the past decade, commercial banks have seen a number of changes in the structure of the market for C\&I loans, and these changes have significantly affected the dynamics of demand and supply at large banks. The rapid growth of the syndicated loan market, the effects of consolidation in the banking industry, and the growing attractiveness of loan assets to institutional investors have boosted the participation of nonbank financial institutions in the market for bank loans. These trends have spawned a relatively active secondary market, in which pieces of: large syndicated loans are traded at market prices. The resulting availability of informative secondary prices on an increasing number of large loans has allowed commercial banks to manage their credit risk more effectively and to price new credit extensions more efficiently. The development of credit derivatives, although used primarily by just a few of the largest banks, has given bankers another tool to manage the riskiness of their loan portfolios.

With better management information systems, banking organizations have improved their ability to evaluate and quantify their risk-adjusted returns on capital for various products. Unlike backup lines of: credit, typical drawn business loans are profitable in themselves, but spreads on larger syndicated loans, especially those to investment-grade firms, tend to be quite narrow. Banks are willing to participate in these credit arrangements in part because by doing so they are more likely to establish a broader relationship with the borrower, which could allow them to sell additional fee-based services to the customer. Moreover, banks earn substantial fees for arranging and servicing these varied credit facilities for large borrowers. In essence, these banks are moving away from their previous "lend and hold" business practices toward a fee-oriented "originate and distribute" business model.

\section{Syndicated Loan Market}

In a syndicated loan, an arranger-almost exclusively a large financial institution or a small group of large institutions-acts like a bond underwriter by soliciting a wide consortium of commercial banks and institutional investors such as investment banks, insurance companies, pension funds, and mutual

financial statements covering periods ending after December 15, 2003, and banks are reportedly continuing to explore ways to avoid consolidation of their $\mathrm{ABCP}$ conduits. 
funds to hold portions of the loan for a large corporate borrower. This type of lending differs from a traditional business loan model, in which a commercial bank originates the loan and keeps the entire loan on its books until maturity. Although the arranger(s) of a syndicated loan usually have a broad relationship with the borrower, as is the case in the traditional lending model, many of the financial institutions in the syndicate are typically not relationship lenders. These financial institutions do not benefit from ancillary business, and as a result, they are especially sensitive to the pricing and risk characteristics of the loan itself. Their sensitivity, in turn, has reinforced banks' attempts to increase fees and spreads on large business loans.

According to the results of the Shared National Credit Survey (SNC), the volume of total commitments (the sum of outstanding loans and unused loan commitments) in the U.S. syndicated loan market grew in real terms from about $\$ 900$ billion in the early 1990 s to almost $\$ 2$ trillion at its peak in 2001; the real volume of outstanding loans also roughly doubled over the same period (chart 26). In the August 2000 BLPS, most banks with assets of more than $\$ 20$ billion indicated that syndicated loans composed a substantial percentage of their total C\&I loans outstanding, and seven banks indicated that the portion was greater than 50 percent. According to the

9. Each year, the Board of Governors of the Federal Reserve System, the Federal Deposit Insurance Corporation, and the Office of the Comptroller of the Currency conduct the Shared National Credit Survey, in which they collect data on the credit quality and other characteristics of all C\&I loans and loan commitments of more than $\$ 20$ million that are held by three or more supervised financial institutions.

26. Real value of total commitments and debt outstanding on syndicated loans, 1989-2003

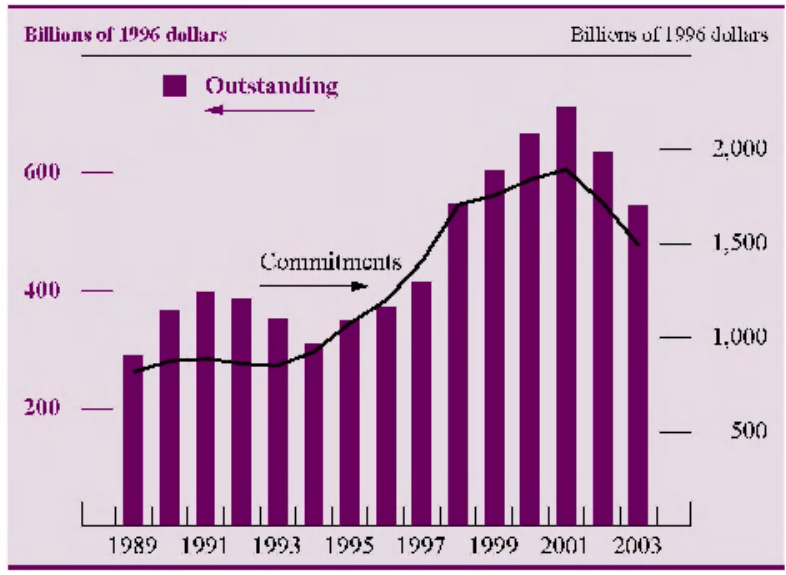

NOTE. Commitments are outstanding debt plus unused commitments. The data are deflated by the price deflator for business-sector output $(1996-100)$. SOURCE. Shared National Credit Survey (see text note 9).
LPC, over the past decade, investment-grade companies have accounted for an average of about twothirds of gross issuance in the syndicated loan market. ${ }^{10}$ The share of gross issuance accounted for by below-investment-grade firms, however, increased somewhat over the past two years, partly reflecting the greater refinancing by such firms and an increased desire to hold these types of assets by nonbanks.

Investment banks are also major participants in the syndicated loan market. During the evolution of the market for business loans, customer demand for one-stop shopping and the entry of commercial bank affiliates into investment banking using section 20 subsidiaries blurred many of the distinctions between investment banking and commercial banking. ${ }^{11}$ The Gramm-Leach-Bliley Act formally acknowledged these market developments and further reduced or eliminated some restrictions on the capital market activities of commercial bank affiliates. This deregulation, in turn, led investment banks to step up the underwriting of syndicated loans so that they could also offer a full range of financing options to their corporate customers. However, investment banks' relatively smaller balance sheets, higher funding costs, and different traditional business models make these institutions more reluctant than banks to retain the loans that they underwrite, especially if the loans by themselves are not profitable enough to meet the internal hurdle rates of investment banks. Investment banks are particularly averse to holding revolving lines of credit, which can result in large, unexpected demands for funds that the investment bank must finance on short notice. Partly to mitigate these problems and partly to compete better in the syndicated loan market, a few investment banks have acquired depository institutions or established them within their holding company structure.

Many other financial institutions - including insurance companies, prime rate funds, and pension funds - have reportedly participated in the syndicated loan market for more than a decade. More recently, the market is said to have piqued the interest of high-yield mutual funds and hedge funds. These institutional participants tend to be interested in term loans or facilities with high utilization, and they do

10. Gross issuance is defined as the sum of new loans and credit lines, increases in the size of existing credit agreements, and the refinancing of existing credit facilities. The LPC only recently began reporting net issuance-new loans and increases in existing credit facilities-separately from refinanced credits.

11. In April 1987, the Board of Governors of the Federal Reserve System reinterpreted section 20 of the Glass-Steagall Act, allowing bank holding companies to establish subsidiaries to conduct certain bank-ineligible investment banking activities, such as underwriting of corporate bonds and equities. 
not deal in ancillary businesses that investment and commercial banks may pursue through a relationship with a borrower (for example, cash management and bond underwriting). As a result, they are most likely to purchase only drawn loans that they view as fully priced to reflect the riskiness of the borrower, and they also prefer loans with longer maturities. Because these characteristics are attached more often to below-investment-grade loans than to the lines of credit for investment-grade firms, institutional investors hold a substantial share of riskier syndicated loans.

Other important pieces of the institutional loan market are special-purpose investment vehicles that purchase and hold loans (collateralized loan obligations, or CLOs) or, more generally, loans in combination with other debt instruments (collateralized debt obligations, or CDOs). Most CLOs and CDOs are not actively managed, partly because accounting conventions make it more likely that actively managed structures will need to be consolidated onto the balance sheet of the sponsoring institution. CLOs and CDOs fund their investments primarily by issuing debt instruments, which are structured to match the investors' risk-and-return profiles through a process called tranching. ${ }^{12}$ Financial institutions sponsor these vehicles to profit from the fees earned for providing these products to their investment customers. Major commercial banks have also used CLOs to move distressed or otherwise unwanted loans off their balance sheets.

The decline in the volume of C\&I loans at commercial banks has been partly offset by increased holdings of such loans by nonbanks, which the SNC defines as independent investment brokerages, investment vehicles (such as CLOs), and other institutional investors. The SNC data show that the share of total syndicated loan commitments held by nonbanks has increased from 8 percent in 2001 to 11 percent in 2003 (table 1). Moreover, a significant and growing portion of the holdings of nonbanks is made up of adversely rated credits, which increased to almost one-fourth of their total commitments in 2003. Nonbanks apparently stepped up the acquisition of adversely rated credits because these loans have a relatively attractive yield-risk tradeoff and their workout can often be quite profitable. Responses to

12. The highest tranche pays investors the smallest return but has the least risk by virtue of having first claim on the cash flows generated by the underlying assets in the CLO or CDO. The middle tranches pay somewhat higher rates of return in exchange for investors' willingness to bear more risk. Investors in the lowest tranche are paid only after all the higher tranches have been paid in full, thus exposing them to the first losses in the portfolio.
1. Share of holdings of syndicated and adversely rated loan commitments, by type of lender, 2001-2003 Percent

\begin{tabular}{|c|c|c|c|}
\hline Loan commitment and holder & 2001 & 2002 & 2003 \\
\hline \multicolumn{4}{|l|}{$\begin{array}{l}\text { Total syndicated loan } \\
\text { commitments }\end{array}$} \\
\hline U.S. banks ......... & 46 & 45 & 45 \\
\hline Foreign banking organizations & 46 & 45 & 44 \\
\hline Nonbanks ${ }^{1} \quad \ldots \ldots \ldots \ldots \ldots$ & 8 & 10 & 11 \\
\hline \multicolumn{4}{|l|}{$\begin{array}{l}\text { Own loan commitments that are } \\
\text { adversely rated }\end{array}$} \\
\hline All institutions $\quad \ldots \ldots \ldots \ldots \ldots$ & 5.7 & 8.4 & 9.3 \\
\hline U.S. banks ....................... & 5.1 & 6.4 & 5.8 \\
\hline Foreign banking organizations .... & 4.7 & 7.3 & 9.0 \\
\hline Nonbanks ${ }^{1} \quad \ldots . . . . . . . . . . . .$. & 14.6 & 23.0 & 24.4 \\
\hline
\end{tabular}

1. Nonbanks include independent investment brokerages, investment vehicles, and other institutional investors.

2. These loan commitments are classified as "substandard," "doubtful," or "loss." Substandard loans are characterized by the distinct possibility that the bank will sustain some loss if the deficiencies are not corrected. An asset classified as doubtful has all the weaknesses inherent in one classified as substandard with the added characteristic that the weaknesses make the collection or liquidation in full highly questionable and improbable. Assets classified as loss are considered uncollectible and of such little value that their continuance as bankable assets is not warranted, even though partial recovery may be effected in the future

SourCE. Shared National Credit Survey.

the October 2003 BLPS suggest that a substantial part of the increase in adversely rated credits at nonbanks may reflect purchases of distressed loans from commercial banks. The most-often-cited reasons that survey respondents gave for selling their adversely rated loans were to trim the overall credit risk of their C\&I loan portfolios and to reduce exposure to particular firms.

\section{Secondary Loan Market}

The growth of the syndicated loan market and the increased participation of institutional investors helped spur the development of a secondary market for trading pieces of syndicated loans. The real volume of loan trading in the secondary market has increased fairly steadily during the past decade, from less than $\$ 20$ billion a year in the early 1990 s to more than $\$ 100$ billion in recent years (chart 27). Trading is most active in the below-investment-grade segment of the market, according to data from the LPC, and an increased percentage of the recent activity has been in distressed assets. The higher trading volumes have made pricing somewhat more transparent for many of the largest and most-liquid loans, for which the industry has taken steps to determine and publish timely market quotes. Nonetheless, liquidity in the secondary market for C\&I loans is reportedly hampered by the assignment fees that banks charge loan investors to cover the cost of transferring ownership in the pieces of loans that are traded. In addition, 
27. Real value of loans traded in the UIS. secondary market, $1991-2003: \mathrm{H} 1$

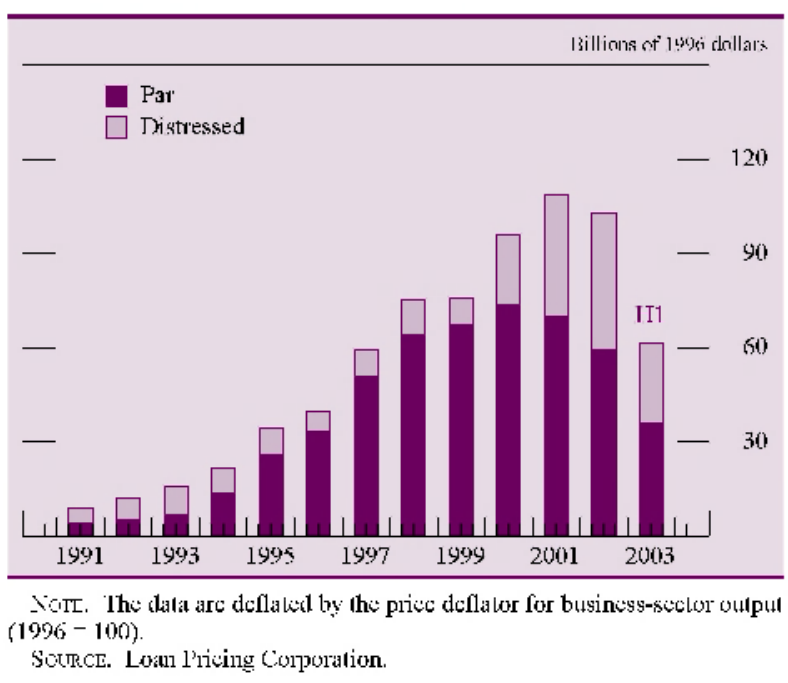

market participants note that the documentation required to trade loans is substantial, and thus the settlement period for loan trades is considerably longer than that for bond or equity trades.

The increased depth of the secondary loan market and the availability of representative price quotes have apparently allowed banks to manage their C\&I loan portfolios more actively. Indeed, during the most recent downturn, a significant number of banks sold distressed loans into the secondary market, a move that allowed them to accelerate charge-of's and thereby reduce delinquencies, as well as to reduce the riskiness of the loans on their books. The existence of representative market quotes on the prices of loans is also important for institutional participants, many of which mark their portfolios to market more regularly than do commercial banks to follow either market convention or regulatory requirements.

The increased liquidity in the secondary loan market has reportedly led to some convergence in bond and loan spreads, especially in the leveraged segment of the market. In the August 2002 BLPS, a significant percentage of larger banks indicated that they considered bond market prices to be helpful for monitoring the credit quality of their business customers. In addition, the pricing for many lines of credit is based on ratings grids, a practice that implies that the firm pays a higher spread on its draws if its credit rating is downgraded and a lower spread if its credit rating is upgraded. Most recently, a few syndicated revolving credit lines have reportedly incorporated bond-linked pricing, in which the spread charged on a draw from the credit line is determined by the prevailing spread on the company's bonds at the time of the draw.

\section{Credit Derivatives}

Some of the largest commercial banks are increasingly using credit derivatives to help manage the riskiness of their business loan portfolios. In one of the most common forms of credit derivative-the credit default swap (CDS) - the beneficiary, an investor that will receive a payment if the issuer defaults or experiences another pre-specified adverse outcome, contracts with a guarantor, a financial institution that will pay the losses in that event. ${ }^{13}$ In return, the beneficiary pays the guarantor a fee equal to a specified number of basis points times the amount of credit protection that it wishes to purchase. The amount charged by the guarantor for the contract is based, of course, on the likelihood that the firm in question will experience a specified adverse credit event and on the expected value of the underlying debt instrument in such circumstances.

The value of credit derivatives purchased and sold by commercial banks has increased rapidly over the past decade (chart 28). However, the overall number of banks that transact in credit derivatives is quite small: As of the third quarter of 2003, the ten largest banks held 97 percent of the total credit derivatives for which banks act as guarantors and 94 percent of the total credit derivatives for which banks are the beneficiaries. A few of the largest banks also act as dealers in the market for credit derivatives and therefore hold substantial percentages of both the industry's beneficiary positions and its guarantor positions. Since 1997, when data on banks' holdings of credit derivatives first became available in the quarterly Reports of Condition and Income (Call Reports), the U.S. banking sector has generally maintained a small net beneficiary position in credit derivatives. However, banks' position as a net beneficiary increased considerably in the first half of 2003, perhaps because of a greater use of these instruments to hedge exposure in their C\&I loan portfolios.

Like corporate bonds and syndicated loans, CDSs are actively traded. Increasingly, loan investors are presented with opportunities for arbitrage when the spreads among these three markets diverge. For example, if the CDS for a particular firm is yielding a higher return than is a loan to the same firm, a bank

13. The treatment of restructuring, in which a firm does not technically default but rather changes the terms on its debt instruments, has presented problems during the development of the CDS market. The International Swaps and Derivatives Association has issued three sets of guidelines to clarify the way in which guarantors and beneficiaries should treat restructuring, and it continues to work toward a standard definition. 
28. Value of credit derivatives held by banks as guarantors and as beneficiaries 1997-2003:03

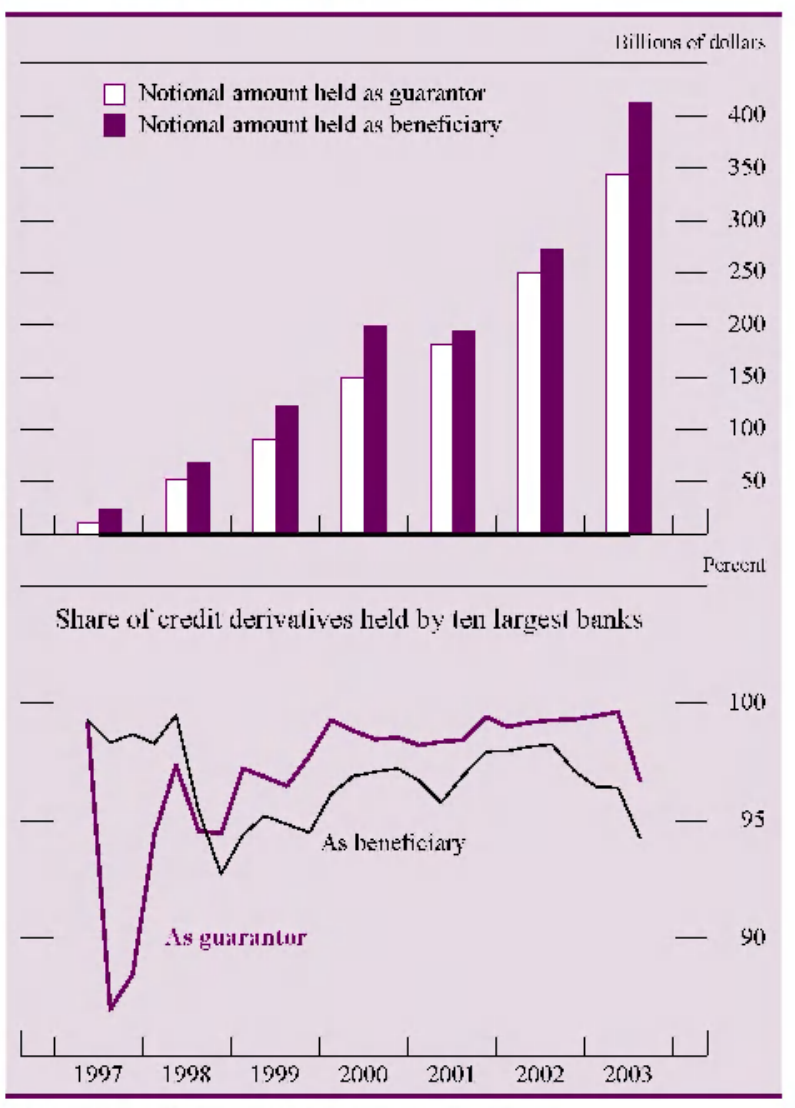

Norti. Percentages are plotted at a quarterly frec|uency.

Sorrce. Call licporls.

that wishes to obtain credit exposure to that firm can choose to act as the guarantor on a CDS for the firm's bonds rather than making the loan. The increasing use of CDSs in managing risk may have also resulted in a greater willingness of banks to make loans to companies for which they can purchase credit protection in the CDS market.

The January 2003 BLPS asked banks why they used CDSs and how their participation in that market had affected the total amount of C\&I loans that they made. The reasons most often cited by banks for selling CDS protection were that it was occasionally more profitable than direct lending and that it helped them diversify credit risk. Banks that had purchased credit derivatives to protect against loan losses overwhelmingly reported that they preferred buying credit protection to selling a loan in the secondary market because the purchase of the CDS did not affect their relationship with the borrower. On net, banks reported that the development of the CDS market had a small positive effect on their supply of business loans.

\section{Industry Consolidation}

Since the passage in 1994 of the Riegle-Neal Act, which phased out many of the barriers to interstate branching by commercial banks, consolidation has accelerated. The 100 largest banks now hold almost 75 percent of total banking assets and 77 percent of outstanding C\&I loans, up from 56 percent and 66 percent, respectively, in 1994 (chart 29). Similarly, the ten largest commercial banks hold 43 percent of total banking assets and 47 percent of outstanding C\&I loans, compared with 25 percent and 28 percent, respectively, in 1994. These increases in industry concentration may be somewhat overstated because of mergers that have occurred among banks that were already within the same holding company; even so, a substantial number of mergers among the largest holding companies have occurred over the same period.

One effect of consolidation on the C\&I loan market is that it has left fewer commercial banks to participate in the syndication process. Reportedly, a merged bank tends to offer smaller loans and credit lines in

29. Concentration in the banking industry among the 10 largest and 100 largest banks, 1988-2003:Q3

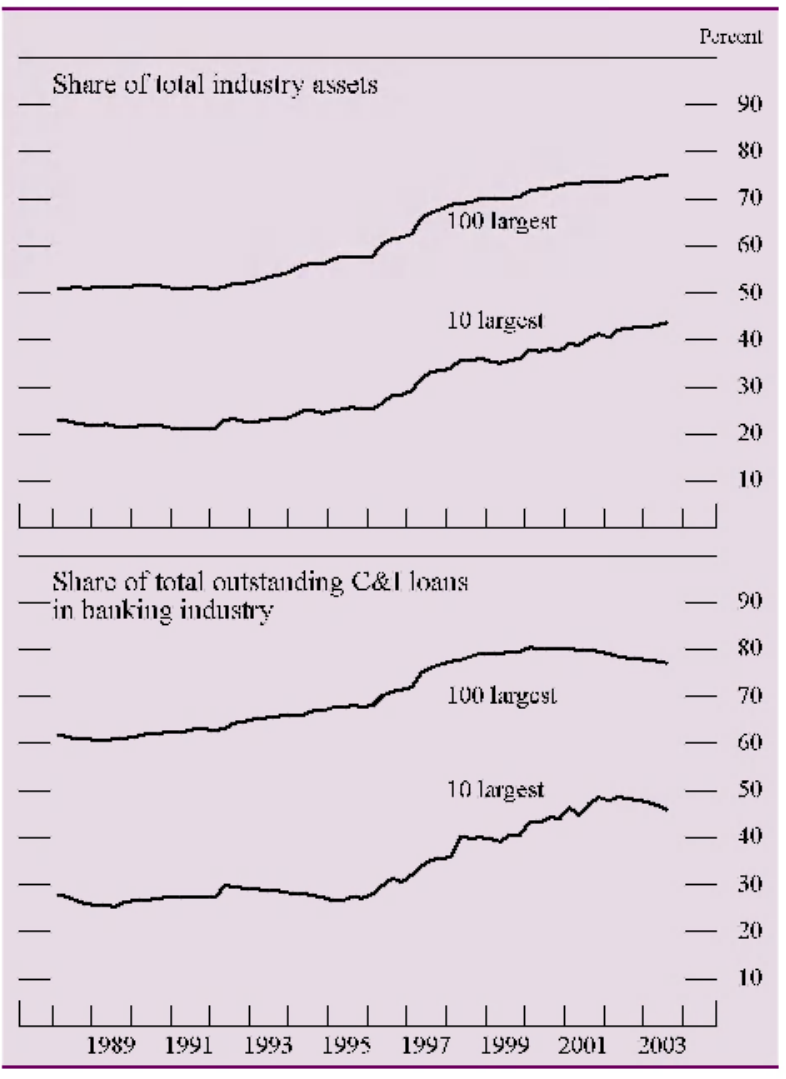

SOURCE. Call Reports. 
the syndicated loan market than the combined amount that the two predecessor banks had offered before the merger. As a result, market participants have argued that consolidation has reduced the capacity of the syndicated loan market to meet the credit demands of some large corporate borrowers. On the other hand, the increased number of institutional participants in that market should have at least partially offset such a decline in lending capacity.

\section{CONCLUSION}

Despite the appreciable deterioration in asset quality and the reduced demand for credit by business borrowers over the past several years, commercial banks have remained highly profitable and well capitalized. In contrast to the 1990-91 period, when large losses held down banks' earnings and eroded their capital, during the recent recession banks were well positioned to lend to creditworthy business customers willing to pay the higher loan fees and lending spreads that banks have increasingly demanded as part of their improved risk management. The economic slowdown and the tightening of credit standards, however, sharply reduced the number of creditworthy firms. Meanwhile, the customers that remained creditworthy generally had less need for external funds.

To help determine the relative importance of the various supply and demand factors contributing to the runoff in C\&I loans, the October 2002 BLPS asked banks to rank several possible reasons for the decline in business loans during the first nine months of that year. More than three-fourths of the respondents indicated that the most important factor behind the sharp contraction in C\&I loans during that period was reduced demand from creditworthy borrowers. The second-most-important factor was that the deterioration in business credit quality had reduced the number of firms that banks viewed as creditworthy. Banks rated the incremental effect of their own efforts to tighten lending standards as only the third-mostimportant factor and stated that increases in spreads and fees on business loans had the least effect on business loan flows. In the opinion of the banks responding to the BLPS, then, the decline in business loans was clearly related more to reduced demand than to restrictions in supply.

Nonetheless, supply effects appear to have played an important role. Staff research suggests that the large banks on the survey panel that most often reported tightening credit standards from 1999 to the end of 2001 experienced the largest contraction in business lending whereas banks that reported tightening in only a few quarters or not at all had a smaller decline in outstanding C\&I loans and credit lines. ${ }^{14}$ Asked why they had tightened lending standards, however, respondents to the BLPS often mentioned industry-specific problems and the resulting decline in the creditworthiness of firms in those industries. That the industries hit hardest by the economic slowdown and other events at the beginning of this decade-telecommunications and airlines, for example-traditionally borrowed from large banks may have magnified the declines in C\&I loans at those banks.

14. See William F. Bassett and Mark Carlson, "Profits and Balance Sheet Developments at U.S. Commercial Banks in 2001," Federal Reserve Bulletin, vol. 88 (June 2002), pp. 259-88. 